\begin{tabular}{lcccr} 
T H E & A R C H I V E & O F & M E C H A N I C A L & E N G I N E E R I N G \\
\hline VOL. LVII & 2010 & Number 1
\end{tabular}

Key words: bearings system, ball bearing, bearing internal clearance, bearing load, bearing durability

ANDRZEJ RACZYŃSKI *, JAROSEAW KACZOR **

\title{
ANALYSIS OF BEARING SYSTEM OF THREE-BEARING SHAFTS WITH RESPECT TO ELASTIC SHIFTS IN BEARINGS
}

\begin{abstract}
Bearings of three-bearing shafts are usually treated as ideally-rigid articulated supports. In literature, the reactions of supports and bending moments of multibearing shafts are calculated taking into consideration only shaft elasticity. In fact, also deformation is present in these bearings, and it changes the shaft bending line. The deformation thus influences distribution of bending moment and reaction of supports. It is the most important difference when comparing two-bearing with threebearing shafts.

Moreover, in most types of bearings, a reactive bending moment is the response of bearing to unparallel position of inner bearing rings in relation to outer rings, that is to the tilt angle. As a result, real loads of rolling elements differ from theoretical ones.

The aim of the paper is to develop a method of calculating generalized loads in rolling bearings of a three-bearing shaft taking into consideration shaft deformation, deformations in bearings and reactive moments of bearings caused by tilt angle.
\end{abstract}

\section{Introduction}

In machine constructions, shafts supported by two bearings are used most commonly. Yet, sometimes the necessity to support the elements set on the shaft requires using additional bearings. Such a situation occurs e.g. in the case of shafts of internal-combustion engines or long transmission shafts. Application of more than two bearings can cause certain installation problems [1], e.g.:

- necessity to arrange all bearings in one axis, since otherwise an additional bending of the shaft and additional load over bearings will occur;

- hindering making more difficult periodical change of bearings.

* Technical University of Lodz, Department of Heating and Ventilation Engineering, al. Politechniki 6 90-92 Łódź, Poland; E-mail: andra@p.lodz.pl

** Technical University of Lodz, Department of Heating and Ventilation Engineering, al. Politechniki 6 90-92 Łódź, Poland; E-mail: jarka@p.lodz.pl 
Also calculating multi-bearing shaft and its bearing system is problematic, because this type of shaft is statically indeterminable. In solutions known from literature, reactions of supports and bending moments in multi-bearing shafts are calculated taking into consideration elasticity of the shaft. Yet in these solutions elasticity of bearings themselves is not taken into consideration; they are treated as ideally-rigid supports with articulation. Whereas in reality deformations exist also in bearings, which causes additional shaft deflection, and thus influences the distribution of bending moment and reactions of supports. Moreover, most bearings (excluding self-aligning bearings) do not fulfill the requirements of articulation. Angular deflection of a shaft in the place it is supported is impeded by a reactive bending moment - a response of the bearing to angular deflection. As a result, bearings are loaded differently than concluded from theoretical model.

\section{Physical model}

Bearing loads and their fatigue life have been calculated for the following bearing system model: machine shaft made of steel is supported by three rolling bearings. The shaft can have changeable section, i.e. it can consist of a series of cylindrical segments. The shaft is elastic, and the relation between load and deflection results from a well-known equation of shaft bending line. Shaft bearings are deep groove (single-row) ball bearings. The bearings are elastic too, and the relation between load and the displacement of an inner ring in relation to the outer one results from geometrical summing up of local loads and Hertz deformation at the point where balls contact the race. Axial load of the shaft is taken up by the left bearing (,A") in the scheme (Fig. 1a). Hence, this is a retaining bearing.

Simplifying assumptions:

- The problem is considered statically (forces and forces changes caused by rotational movement of the shaft and inner elements of bearings have been omitted).

- Shaft loading occurs in one axial plane and is represented by component forces acting in radial $x$ and axial ydirection.

- Elastic deformations of bearings occur only in places where rolling parts contact with rings (free surfaces of rings keep their cylindrical shape).

- Mounting of bearings is geometrically perfect, i.e. axes of outer bearing rings are situated along one straight line.

- Setting of bearings is ideally rigid (outer rings of bearings do not displace).

- Bearings clearances have been omitted. 


\section{Solution method}

Due to interdependence between the considered values (deformations and loads in shaft and bearings) as well as the impossibility to directly calculate components of displacement in a bearing depending on a load, the following iterative procedure was taken:

1. In the first step, reference reactions of supports and reference parameters of shaft bending line are roughly calculated without taking into consideration elasticity and reactive moments of bearings. These assumptions can be presented in the following form:

$$
\varphi_{A} \neq 0 \quad y_{A}=0 ; \quad \varphi_{B} \neq 0 \quad y_{B}=0 ; \quad \varphi_{C} \neq 0 \quad y_{C}=0
$$

where:

$\varphi$ - angle of shaft deflection on particular supports,

$y$ - shaft deflection on supports.

In order to make these calculations for a three-bearing shaft, the rule of superposition [2], [3] has been used, which is illustrated in Fig. 1. First of all, reactions and parameters of bending line of a shaft supported in points $\mathrm{A}$ and B (Fig. 1b) are calculated. For the purpose of determining parameters of a bending line, a numerically developed analytic method has been applied. The first stage is to determine a fictitious load representing the field of a diagram of bending moments. In the case of a shaft with changeable diameter, reduction of bending moments is introduced depending on the moment of inertia of $I$ section. Fictitious bending moment $M_{g f}$ resulting from fictitious load determines the value of shaft deflection $y$, and fictitious shearing force $T_{f}$ - angle of shaft deflection $\varphi$, in accordance with the following relations:

$$
y=\frac{M_{g f}}{E \cdot I_{\max }} \quad \varphi=\frac{T_{f}}{E \cdot I_{\max }}
$$

where:

$E$ - substitute modulus of elasticity; for steel $\mathrm{E}=227100 \mathrm{MPa}$,

$I_{\max }$ - maximum moment of inertia.

After thus calculating the deflection $y_{1}$ in point $\mathrm{C}$, one proceeds to the scheme void of outer forces, presented in Fig. 1c, and calculates force $R_{c}$ necessary in point $\mathrm{C}$ for compensating $y_{1}$ deflection with $y_{2}=-y_{1}$ displacement. Reactions of A and B supports and parameters of bending line are added respectively to reactions and parameters in the first diagram, which leads to determining real reactions of supports and the line of a three-bearing shaft deflection. Thus deflection angles upon supports of a three-bearing shaft shall be: 


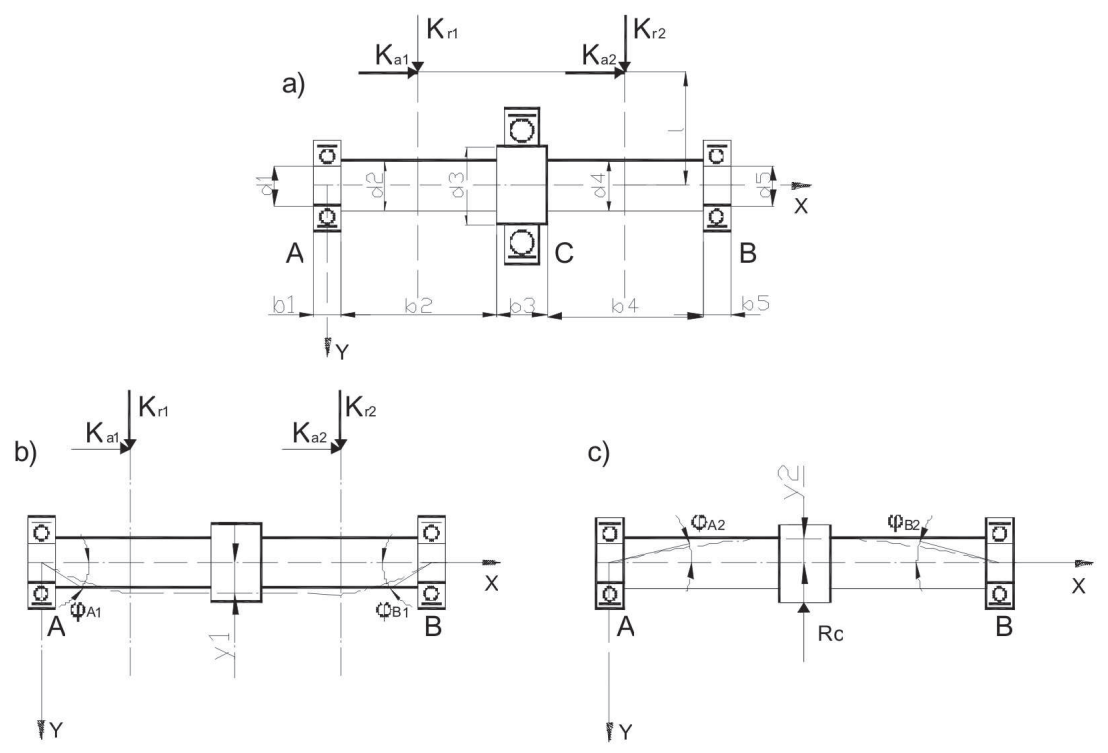

Fig. 1. Rule of rough determining of referential shaft bending line

$$
\varphi_{A}=\varphi_{A 1}+\varphi_{A 2} \quad \varphi_{B}=\varphi_{B 1}+\varphi_{B 2} \quad \varphi_{C}=\varphi_{C 1}+\varphi_{C 2}
$$

In the above procedure, elastic displacements in bearings were not taken into consideration yet (in accordance with the notation (1)). Thus fictitious elastic displacements in bearings equal zero.

2. In the second step, elastic displacements in bearings and reactive moments of bearings are determined for their initial loads and initial parameters of a shaft bending line.

There exists a non-linear relation between the angle of deflection of bearing rings and the reactive moment of a bearing. As the angle increases, contact stresses in the bearing increase nonlinearly, despite constant value of the forces loading the bearing, which results in rapid shortening of its life. It is practically impossible to determine elastic displacements in a bearing (linear dislocations and tilts between rings) basing on bearing load, because the number of balls under load, distribution of balls loads and angles of action of particular balls in the bearing are not known. Reverse acting is only possible, as presented in [4] and proposed in publications [5], [6]. There is assumed the linear dislocation of inner ring with reference to the outer one in three directions $f_{x}, f_{y}, f_{z}$ (where $\mathrm{X}$ is the axis of the bearing and $\mathrm{Y}$ and $\mathrm{Z}$ axes are perpendicular to it) as well as inner ring tilts in relation to the outer one in two plains $\left(\varphi_{y}-\right.$ in plane $\mathrm{X}-\mathrm{Z}$ and $\varphi_{z}$ - in plane $\left.\mathrm{X}-\mathrm{Y}\right)$ ) (Fig. 2). 

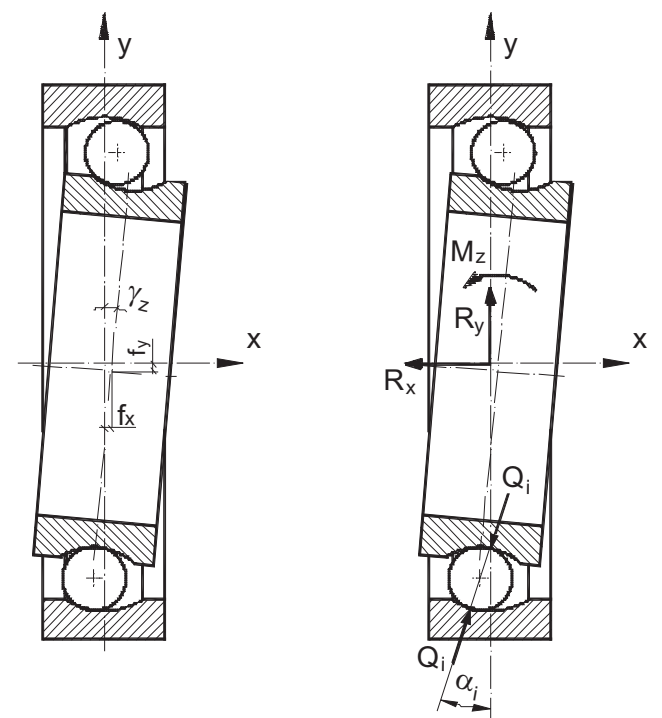

Fig. 2. Displacements and reactions in bearing

On these bases, the angles of balls acting $-\alpha$ (angles at which the balls carry a load) and deformations at the contact point of particular balls with rings are calculated. Depending on these deformations, normal forces $Q_{i}$ are defined for all balls. These forces are the basis for calculating the resultant forces $R_{x}, R_{y}, R_{z}$ and reactive moments of the bearing $M_{y}, M_{z}$ defined by formulas $(2 \div 6)$, that is equal to external forces and moments acting upon the bearing:

$$
\begin{gathered}
R_{x}=\sum_{i=1}^{Z}\left(-Q_{i} \sin \alpha\right) \\
R_{y}=\sum_{i=1}^{Z}\left(-Q_{i} \cos \alpha \cos \psi\right) \\
R_{z}=\sum_{i=1}^{Z}\left(-Q_{i} \cos \alpha \sin \psi\right) \\
M_{y}=\sum_{i=1}^{Z}\left(Q_{i} r_{p} \sin \alpha \sin \psi\right) \\
M_{z}=\sum_{i=1}^{Z}\left(Q_{i} r_{q} \sin \alpha \cos \psi\right)
\end{gathered}
$$




$$
\begin{aligned}
& r_{p}=0.5 d_{m}-0.5 d_{k}-0.25 \Delta_{r}+r_{i} \\
& r_{q}=0.5 d_{m}+0.5 d_{k}+0.25 \Delta_{r}-r_{o}
\end{aligned}
$$

where:

$\alpha$ - angle of acting (loading) of a considered ball in the axis plane of a ball,

$\psi$ - nominal angle of position of the ball in the frontal plane of the bearing,

$r_{p}$ - polar coordinate of the centre of transverse curvature of the inner ring race in the contact point with a selected ball in a nominal position (without displacements),

$r_{q}$ - polar coordinate of the centre of transverse curvature of outer ring race in the contact point with a selected ball in a nominal position (without displacements),

$d_{m}$ - mean diameter of the bearing; $d_{m}=0,5(d+D)$,

$d$ - inner diameter of the bearing,

$D$ - outer diameter of the bearing,

$d_{k}$ - diameter of the ball in the bearing,

$\Delta \mathrm{r}$ - radial clearance in the bearing,

$r_{i}$ - transverse radius of the inner ring race,

$r_{o}-$ transverse radius of the outer ring race

With a trial-and-error method, such an elastic displacement on the bearing can be found, for which the assumed values of radial and axial load, in this case initial load, are observed.

3 . In the third step, the end values of reaction and end parameters of shaft bending line are determined.

Displacement $f_{y}$ in the bearing corresponds with $y$ shaft deflection on the support, while tilt $\gamma_{z}$ equals the angle $\varphi$ of shaft deflection on the support. Still previously described solution for shaft bending line does not provide proper values of deformations, because in shaft load reactive moments of bearings and in shaft deformation the bearings elasticity were not taken into consideration. Moreover, displacements of bearings $y$ cause changes of deflection angles on supports, while the value of angle of deflection of every support is influenced by deflections of other supports. For the purpose of taking these relationships into consideration, an iterative process has been introduced, in which by the method of successive approximations conformity of loads and deformations in the shaft and bearings was achieved. In the applied method of calculating the shaft deflection, the displacements of bearings $f_{y}$ are considered in the form of fictitious bending moments working on supports and calculated depending on: 


$$
M g_{f}=f_{y} \cdot I_{\max }
$$

Only axial displacement $f_{x}$ does not have any influence on shaft deflection on supports.

Finishing of the iterative process means that values of forces loading all balls in every bearing can be regarded as fulfilling the equilibrium conditions. Knowledge of these forces makes it possible to calculate a mean loading of a ball:

$$
Q_{r}=\left(\frac{1}{Z} \sum_{i=1}^{Z} Q_{i}^{3}\right)^{1 / 3}
$$

where:

$Q_{r}$ - mean loading of balls,

$Z$ - number of balls in a bearing,

$Q_{i}$ - force acting upon the ball No „i”,

which in turn enables calculating equivalent load of a bearing according to Sjövall [7]:

$$
P=Z \frac{J_{r}(\varepsilon)}{J_{1}} Q_{r}
$$

where:

$P$ - equivalent bearing load,

$J_{1}, J r(\varepsilon)$ - Sjövall's integral.

Then, it is possible to calculate the fatigue life of a bearing following a well-known Lundberg-Palmgren model [8]:

$$
L_{10}=\left(\frac{C}{P}\right)^{3}
$$

where:

$L_{10}$ - basic rating life of a bearing, millions of revolutions,

$C$ - basic dynamic load rating of a bearing.

With the use of the relations presented above, a computer application has been developed for calculating of dynamic bearing load and basic rating life taking into consideration not only shaft deflection but also deformation in bearings and reactive moments of bearings. Below an example of calculations made with the use of this method is presented. Calculations were made for a simple three-bearing arrangement loaded by two radial forces and two axial forces (Fig. 3). Table I presents comparison between selected results out of two versions of calculations: version a - without taking into account elasticity 
of bearings and without reactive moments, and version $b-$ with taking into account these parameters.

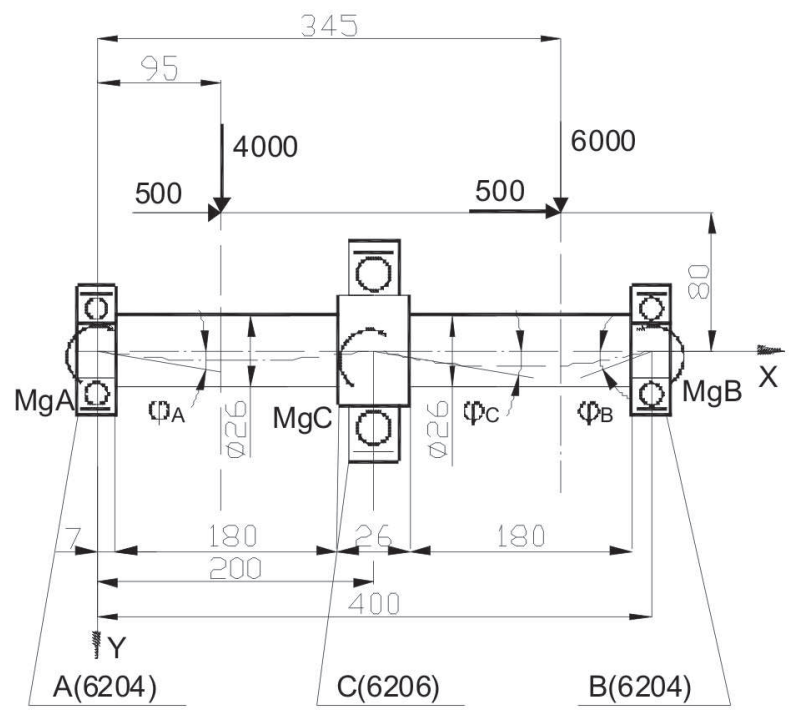

Fig. 3. Bearing system accepted for exemplary calculation

Comparison of results

Table 1.

\begin{tabular}{|c|c|c|c|c|c|c|}
\hline \multirow{2}{*}{} & \multicolumn{2}{|c|}{ Bearing A } & \multicolumn{2}{c|}{ Bearing B } & \multicolumn{2}{c|}{ Bearing C } \\
\cline { 2 - 7 } & $\begin{array}{c}\text { Calculations } \\
\text { in version a }\end{array}$ & $\begin{array}{c}\text { Calculations } \\
\text { in version b }\end{array}$ & $\begin{array}{c}\text { Calculations } \\
\text { in version a }\end{array}$ & $\begin{array}{c}\text { Calculations } \\
\text { in version b }\end{array}$ & $\begin{array}{c}\text { Calculations } \\
\text { in version a }\end{array}$ & $\begin{array}{c}\text { Calculations } \\
\text { in version b }\end{array}$ \\
\hline $\begin{array}{c}\text { Reaction } \\
R_{x}[\mathrm{~N}]\end{array}$ & -1000 & -1000 & 0.00 & 0.00 & 0.00 & 0.00 \\
\hline $\begin{array}{c}\text { Reaction } \\
R_{y}[\mathrm{~N}]\end{array}$ & -1466.54 & -1474.43 & -3316.54 & -3357.43 & -5216.92 & -5168.14 \\
\hline $\begin{array}{c}\text { Shaft } \\
\text { deflection } \\
y \text { [mm] }\end{array}$ & 0 & $1.3481 \cdot 10^{-2}$ & 0 & $3.6426 \cdot 10^{-2}$ & 0 & $4.1865 \cdot 10^{-2}$ \\
\hline $\begin{array}{c}\text { Angle of } \\
\text { shaft } \\
\text { deflection } \\
\varphi[\text { rad.] }\end{array}$ & $1.0423 \cdot 10^{-3}$ & $9.0908 \cdot 10^{-4}$ & $-1.9420 \cdot 10^{-3}$ & $-2.0039 \cdot 10^{-3}$ & $1.9303 \cdot 10^{-4}$ & $3.0312 \cdot 10^{-5}$ \\
\hline $\begin{array}{c}\text { Life of } \\
\text { bearings } \\
L_{10} \\
{[\text { millions }} \\
\text { of } \\
\text { rotations] }\end{array}$ & $1.02 \cdot 10^{1}$ & $1.78 \cdot 10^{1}$ & $2.74 \cdot 10^{1}$ & $2.64 \cdot 10^{1}$ & $2.02 \cdot 10^{1}$ & $2.00 \cdot 10^{1}$ \\
\hline
\end{tabular}

The above calculations have proved significant influence of elasticity of bearings and reactive moments resulting from angular tilts in bearings on 
durability of the bearing system. Other calculations show that the scale of this influence depend on, among others, the size of bearings, geometrical relations in the bearing arrangement, the kind of loading and the value of forces loading the shaft.

Manuscript received by Editorial Board, December 21, 2009; final version, February 09, 2010

\section{REFERENCES}

[1] Dąbrowski Z.: Wały maszynowe. PWN, W-wa 1999.

[2] Niezgodziński M., Niezgodziński T.: Wytrzymałość materiałów. PWN W-wa 1998.

[3] Twardosz F.: Wytrzymałość materiałów. Wydawnictwo Politechniki Poznańskiej 1983.

[4] Andreason S.: On load distribution in rolling bearing with special reference to the influence of bearing misalignment. Praca doktorska, Chalmers University, Göteborg, 1973.

[5] Kaczor J., Raczyński A.: Trwałość zmęczeniowa łożysk kulkowych zwykłych z uwzględnieniem luzu łożysk i ugięcia wału trzypodporowego. Przegląd Mechaniczny 3, 2007 s. 17-20.

[6] Kaczor J., Raczyński A.: Wpływ współczynnika przylegania na obciążenia i naprężenia w łożyskach wału trzypodporowego. Przegląd Mechaniczny 11, 2008 s. 38-41.

[7] Sjövall H.: Belastingsfördelingen inom kul-och rullager vid yttre radial-och axialbelastiningare. Tekn. Tidkrift mekanik 1938.

[8] Lundberg G., Palmgren A.: Dynamic Capacity of Rolling Bearings. Acta Polytechn., Mech. Eng. Series, Royal Swedish Acad. Of Eng., Sc. Vol. 1, Nr 3,7/1947.

\section{Łożyskowanie wałów trzypodporowych z uwzględnieniem przemieszczeń sprężystych w łożyskach}

\section{Streszczenie}

Łożyska wału trzypodporowego traktuje się zazwyczaj jako podpory doskonale sztywne o charakterze przegubowym. W rozwiązaniach znanych z literatury reakcje podpór i momenty gnące wałów wielopodporowych są obliczane przy uwzględnieniu sprężystości wału, ale bez uwzględnienia sprężystości podpór. W rzeczywistości w łożyskach również występują odkształcenia, które zmieniają ugięcie wału. Te odkształcenia wpływają zatem na rozkład momentu gnącego i na reakcje podpór. Jest to najistotniejsza różnica między rozważaniami dotyczącymi wałów dwupodporowych i trzypodporowych.

Ponadto w większości rodzajów łożysk pojawia się reakcyjny moment gnący jako odpowiedź łożyska na nierównoległe ustawienia pierścieni wewnętrznych łożyska względem pierścieni zewnętrznych czyli na wychylenie kątowe. W efekcie, obciążenia części tocznych różnią się od obciążeń teoretycznych.

Celem tej pracy było uzyskanie metody obliczania obciążeń uogólnionych w łożyskach tocznych wału trzypodporowego z uwzględnieniem odkształcenia wału, odkształceń w łożyskach i momentów reakcyjnych łożysk wywołanych wychyleniem kątowym. 